\title{
State and law: transformation vectors in modern conditions
}

\author{
Nadezhda Stepanovna Nizhnik*, Maksim Viktorovich Bavsun, Yakub Lomalievich Aliev, \\ Pavel Aleksandrovich Astafichev, and Anatoliy Sergeevich Kvitchuk
}

Saint Petersburg University of the Ministry of Interior of Russia, Department of Theory of State and Law, Saint Petersburg, Russia

\begin{abstract}
Contemporaneity represents an epoch of qualitative changes in social life, which creates due grounds for different scenarios of development of the state and law. The concern for the prospects of state/legal organisation of the society has placed the problem of transformation of the state and law in the centre of scientific conceptualisation, made it a subject of heated debate and accounted for the creation of annalistic history. The authors of the article take part in the polylogue on the given subject by formulating their position on the future of the cultural phenomena - the state and the law. The philosophical/legal research is based on the recognition of the fact that the global scientific revolution has in fact become a reality, and there are due grounds for the formation of the post-classical legal science. The complexity and multidimensionality of the subject of the research - the prospects of transformation of a nation state and law in the conditions of contemporaneity - required a resort to interdisciplinary methodology. The accomplished research largely relied on the anthropocentric approach that allowed the authors to focus on a human being and its consciousness, considering that the latter has an ability to adapt to the challenges of globalisation and the development of digital technologies. As a result of the research, the authors came to the conclusion that the modern state is transforming and acquiring new characteristics under the powerful influence of globalisation processes. The claims of scholars who presume that the state will wither in the foreseeable stage of human development were subjected to criticism. The authors believe that the state continues to be the core of social organisation and adapts to the challenges and threats of the modern time by acquiring new characteristics. Transformation takes place as well in the sphere of legal regulation. The law is comprehended not just as a set of norms or daily activity of people aimed to realise these norms. The law is realised to construct the reality; at the same time the law as such becomes an object of influence of social transformation processes following which the content, forms, legal systems, as well as the mechanisms of law development and law enforcement, undergo changes. An important component of changes is transformation of the philosophical core of law reflecting the processes of change in the paradigm of values.
\end{abstract}

\footnotetext{
* Corresponding author: n.nishnik@bk.ru
} 
Keywords: state, law, authority-compliance governance

\section{Introduction}

The world order in the present-day conditions acquires new characteristics not only in the geopolitical context. The presence of global social-transformation processes in the humanitarian discourse is no longer doubted by modern scholars. The modern world determinants - being a result of the long evolution of the human society - are represented, as viewed by the scholars, by globalisation and rapid development of information, telecommunication, bio- and nanotechnologies which shape the vectors of transformation of the state/legal organisation of the society and condition the modification of social relations regulators.

The globalisation phenomenon and the formation of the integrated socio-economic, information/communication, political/legal system - i.e. the global world community capture the attention of various-profile scientists from different countries. Although the unanimity of views on the driving forces of globalisation has not yet been achieved among the researchers, its objective nature is not a subject of disagreement of the scholars. The theoretical basis for research of various aspects of globalisation is formed by a corpus of essays: those by U. Beck, J. Bell, Z. Brzezinski, I. Wallerstein, A. Giddens, Ya.I. Gilinsky, N.I. Grachev, M.V. Elizarov, I.A. Ilyin, V.L. Inozemtsev, M. Castells, D.A. Kerimov, H. Kissinger, I.I. Lukashuk, V.Ya. Lubaschitz, M.N. Marchenko, A.I. Neklessa, Yu.A. Nisnevich, J. Naisbitt, I.I. Osvetimskaya, A.S. Panarin, R. Robertson, J. Rosenau, G. Thompson, M. Waters, A.I. Utkin, Th. Friedman, F. Fukuyama, S. Huntington, D. Held, P. Hirst, V.E. Chirkin, P. Aburdene, etc. These researchers come to a reasoned conclusion that there is not a single sphere of social life not affected by the globalisation processes. Both the political/legal organisation of the society and the system of regulators capable of producing an effective impact on social relations in the modern world are subjected to the influence of globalisation.

The use of digital technologies in all spheres of human life has become an important characteristic of the modern world. They have a significant impact on social relations by transforming them and promoting their penetration into the virtual environment, which, in turn, requires the law to adapt to the new models of political and legal organisation and the new environment of social regulation.

Identifying the aspects of change in the political and legal organisation of the society and the law in the modern world, in conjunction with philosophical and legal interpretation of these transformation processes, is an important task for contemporary researchers.

\section{Methods}

The methodology of philosophical/legal research represents not solely a system of methods through which the surrounding reality is cognised, but the way to construct an object of scientific research, the way to present "ontology as a picture of existence of an object" [1, p. 117].

Considering the complexity and multidimensionality of the explored subject and the fact that interdisciplinary and problem-oriented forms of research are in the foreground [2], the method of materialistic dialectics was used by the authors as the main, integrative method, which makes it possible to characterise the modern state as a complex integral entity having inherent direct and interdependent relations with the social reality and continuously developing in the conditions of adaptation of the state to globalisation processes. The scientific methods of legal research used in the study were as follows: general (analysis, 
synthesis, generalisation, abstraction, historical method) and special (formal/legal, historical/legal, comparative/legal, method of interpretation of statutory legal acts). In addition, systemic, structural/functional, systemic/informational methods were of particular importance for the research. The attention to semiotic symbols through which the rules of law are enshrined required a resort to hermeneutics as a scientific domain, and within its framework - to the method of interpreting legal texts, the method of discourse analysis. The research was made with the use of anthropocentric approach which makes it possible to focus on the personality and its consciousness adapting to the challenges of globalisation and the development of digital technologies.

\section{$3 \quad$ Results}

The modern state, under the powerful influence of globalisation processes, is transformed and acquires new qualities. The prospects associated with existence of the state have been assessed differently by the researchers. In particular:

- U. Beck, H. Bull, J. Weiler, A. Negri, K. Ohmae, D. Held deem that the modern state is gradually transforming into a non-functional institution, a relic of the bygone era;

- A. Giddens, R. Jackson, B. Jones, V. N. Kudryavtsev, G. V. Maltsev, M. N. Marchenko, M. Walzer, V. E. Chirkin emphasise that despite the ongoing transformation in the context of globalisation, the state still retains its position as the main political organisation on a global stage.

The basis for formation of diametrically opposite estimates of state development prospects is multidimensionality of the nation state as a phenomenon, the complexity of functioning of the state-organised society and a set of vectors fixing possible directions of state development. The researcher plays an important role in implementation of research and formulation of evaluative conclusions regarding the state and the law: the scholar has a certain set of personal qualities, due knowledge of the state/legal-specific phenomena; he proceeds from the personally chosen methodological guidelines. The account of achievements of modern humanitarian science, reflected in the results of research by modern Russian and foreign various-profile scholars, along with the analysis of the law-specific reality at the national and supranational level, undertaken with the use of selected methods, allows the authors to make a conclusion on transformation of the state and its inherent properties in the sphere of law-making and law-enforcement, while not belittling the importance of the state and law in contemporary conditions.

The new environment for the functioning of the modern state and law is represented by a world in which:

- all the components are factually interconnected and testify to the coherence of social processes on a global scale [3-4];

- attempts to establish a world order and to form world ideologies are made [5];

- certain transition from one system of values to another takes place;

- convergence of states and nations in a differing reference space takes place, along with the creation of supranational structures and their growing influence on the regulation of social relations;

- the mechanisms for realization of the sovereignty of national states are changing [6, pp. 6-7], [7];

- mass migration takes place - an important factor for the formation of multicultural societies;

- the processes of legal convergence and legal acculturation take place at an accelerated pace [8];

- transnational corporations have duly developed, stimulating intense international trade and economic relations between far-apart parts of the planet; 
- transnationality has become a feature of social and political processes that serve as a determinant of political globalisation;

- planetary mass media have been created, that efficiently promote the expansion of the Western culture into all regions of the world $[6, \mathrm{p} .6]$;

- the role of the subjective factor in governance has increased significantly;

- globalisation and internationalisation of various deviant manifestations have taken place, with the following determinants: conflicts of international actors' interests; problems of legal regulation of economic integration; restricted sovereignty of states in the conditions of development of integration processes in favour of supranational integrative structures and transnational companies; transformation of social norms expressed in the decline of moral and ethical foundations, spread of cults of violence, crisis of the institution of the family; globalisation of the information space.

The modern epoch has also brought about significant changes in the scientific perception of the world. These changes have been recognised by the scientific community as "the fourth global scientific revolution" [2], as a basis for the formation of post-classical legal science [1]. The state, treated as an objective, stable and regular system in the epoch of classical rationality, is viewed in post-classical jurisprudence as a phenomenon reproduced by the social activity of a subject, as a system constructed under conditions of a non-objective preset $[9$, p. 8]. The state becomes characterised by:

- continuous variability;

- intersubjectivity - the interdependence of the objective and subjective aspect;

- instability (due to reduced manageability inherent in the "risk society");

- historical and socio-cultural contextuality [9, p. 8].

Multidimensionality of law is becoming a principle of the modern legal framework. The legal reality is constructed by the everyday actions of legal entities. "The legal norm, originally represented in a symbolic form, acquires its meaning, being expressed in concrete actions of these subjects" $[10,11]$. With this approach, the law, being a cultural phenomenon, is treated "not as a system of norms, but as daily activities of people aimed to realise them" [1, p. 648]. Law becomes a tool for constructing social reality, while the subject of law, vested with law enforcement powers, becomes a centre of the legal system [12, p. 15]. The efficacy of impact of law on social relations, on the vector of this impact and mass behaviour aimed at enforcement of legal prescriptions - all of the above depends on legal consciousness of the subject of law. Therefore, it is no coincidence that the importance of understanding the mechanisms aimed to overcome legal nihilism is growing.

The change of rationality requires reinterpretation of law as a social regulator. Law follows changes in the society, gets included in civilisational transformation processes. At the same time, the law becomes an object of influence of social transformation as such, following which the content, forms, systems of law, the mechanisms of law development and law reinforcement undergo changes; the conceptional basis of law is transformed.

\section{Discussion}

The study of the state and law transformation processes, as well as the determination of vector of their future changes, resulted in the creation of a number of theories:

- the theory of the transnational state by U. Beck [13],

- the post-national constellation theory by J. Habermas [14],

- the theory of the network society by M. Castells [15],

- I. Wallerstein's world-system theory [16],

- the theory of cosmopolitan democracy by D. Held $[3,4,17]$,

- K. Dzhouitt's concept of the "new world disorder" [18],

- K. Ohmae's ideas of the end of the nation state [19], 
- G.H. von Wright's theory of withering away of the nation state [20],

- F. Fukuyama's forecasts of hybridisation of the human society and its differentiation into biological castes [21].

The arguments proposed by the authors do not exclude our assurance that the state, which undergoes essential transformation through adapting to the challenges of the modern world, remains the core principle of social organisation of the modern world. The scenario of global state/legal evolution provides for creation of a multi-civilisational model of the world order, characterised by equality of cultures and civilisations, "the non-hierarchical conjunction of the universal and the epichorial in law" [11, p. 15].

\section{Conclusion}

The era of intense social transformation and qualitative changes, with the advancement of different development scenarios, has become a reality. Legal science has to search for answers to the challenges of contemporaneity, while primarily problematising the issues related to the content and forms of the state and law.

Globalisation, which predetermines coherence of the planetary society, becomes a determinant of a new historical type of statehood, the modern state.

Nation states get involved in globalisation processes to varying degrees, demonstrating different aspirations as to the use of benefits of ambivalent globalisation for the solution of problems that are relevant for the realisation of public, corporate and individual interests.

Social processes have a multi-directional focus:

- globalisation trend: towards the formation of a global community - the integrated social/economic, information/communication, political/legal system; participation of nation states in integration processes;

- anti-globalisation trend: expressed in the processes of disintegration, regionalisation, localisation, aspiration to preserve the national identity and uniqueness of the legal culture.

The state acquires the status of the inclusive entity; the prerequisite for its functioning is consideration of requirements of international legal norms. The acquired transnational nature of social and political processes is a precondition for intensive international cooperation which is becoming a real necessity in the current context.

Exclusive control and national jurisdiction over own territory get weakened in the context of globalisation. A specific feature of contemporaneity is the extended scope of international bodies and devolution of powers to them in respect of the issues formerly pertaining to the exclusive competence of nation states.

Despite the fact of involvement of the state in intensive integration processes, globalisation does not belittle its importance, nor does it predetermine the inevitability of its withering or weakening. The society, in the conditions of the new epoch, gets restructured, has its state/legal organisation modified; and it treats own presence in supranational bodies as a special way to uphold the national interests.

The law, in the conditions of contemporaneity, exists as a phenomenon with the content and forms conditioned historically and socio-culturally; its significance defines the activities of individuals who construct the legal reality through their mental and behavioural activity [22, p. 132].

The digital environment formed in the context of globalisation provides for new opportunities to influence the legal consciousness of subjects of law, turning it into an object of manipulation [23, pp. 34-35]. The legal consciousness of a subject of law, under the pressure of manipulations, undergoes changes that entail the transformation of the social relations legal regulation model.

The level of technological development today makes it possible to overcome the laws of nature and the boundaries between nature and culture. New social relations become involved 
in legal regulation - those that previously did not exist or did not require legal regulation, or could not be regulated by law objectively. The study of patterns of transformation in the sphere of legal regulation may contribute to the elaboration of predictive scenarios for the development of law.

The legal order, representing a complex self-developing system, should be considered with regard for the programmes of its self-regulation and reproduction. The domain of modern transformation of law, its digitalisation, law-enforcement framework dynamics, needs fundamental research with regard for the identified trends of its development which include:

- the transition from the monocivilisational to multicivilisational model of the world order;

- the transition from the hierarchical-pattern correlation of the universal and national in law towards the combination of the universal, panhuman and epichorial in it;

- the extension of the scope of the interaction of technical, ethical and legal regulation.

\section{References}

1. I.L. Chestnov, Postklassicheskaya teoriua prava [Post-Classical Theory of Law] (ALEF-Press Publ., Saint Petersburg, 2012)

2. V.S. Stepin, Sovremennye tsivilizatsionnye krizisy i problemy novykh strategiy razvitiya [Modern Civilisational Crises and the Problems of New Development Strategies] (Moscow, 2018)

3. D. Held, A. McGrew (eds.), Global transformation, vol. 4: Globalization Theory: Approaches and Controversies (Polity, Oxford, 2007)

4. D. Held, A. McGrew, D. Goldblatt, J. Perraton, Global Transformation: Politics, Economics and Culture (Stanford University Press, New York, 1999)

5. W. Kymlicka, Liberalism, Community, and Culture (Oxford University Press, Oxford, 1991)

6. A.V. Zakharov (ed.), Gosudarstvo, pravo, obshchestvo v usloviyakh globaliziruyushchegosya mira [State, Law, Society in a Globalising World] (Prospect Publ., Moscow, 2017)

7. J. Guehenno, The End of the Nation State (University of Minnesota Press, Minneapolis, 2000)

8. A. Giddens, The Consequences of Contemporaneity (Stanford University Press, Cambridge, 1990)

9. I.I. Osvetimskaya, The state in the conditions of globalisation: theoretical research of legal issues: Abstract of a doctoral thesis (Saint Petersburg, 2016)

10. N.N. Chernogor, D.A. Pashentsev, Journal of Russian Law, 10, 2017

11. T.Ya. Khabrieva, N.N. Chernogor, Budushchee prava. Nasledie akademika V.S. Stepina i akademicheskaya nauka [The Future of Law. The Legacy of Academician V.S. Stepin and Legal Science] (Infra-M Publ., Moscow, 2021)

12. D.A. Pashentsev (ed.), Tsifrovizatsiya pravotvorchestva: poisk novykh resheniy [Digitalisation of Lawmaking: The Search for New Solutions] (Infra-M Publ., Moscow, 2019).

13. U. Beck, Logos 1(4), 2002

14. J. Habermas, Est li budushchee u natsionalnogo gosudarstva [Does the nation-state have a future?], in D.A. Sklyadnev (ed.), Vovlechenie drugogo: ocherki politicheskoy 
teorii [Die Einbeziehung des Anderen. Studien zur politischen Theorie], transl. from German by Yu.S. Medvedev (Moscow, 2001)

15. M. Castells, The Information Age: Economy, Society and Culture, vol. I: The Rise of the Network Society (Blackwell Publishers, Cambridge MA, Oxford UK, 1996)

16. I. Wallerstein, The Modern World-System I: Capitalist Agriculture and the Origins of the European World-Economy in the Sixteenth Century (Studies in Social Discontinuity) (Academic Press Inc., New York, 1974)

17. D. Held, Democracy: From City-states to a Cosmopolitan Order?, in R.E. Goodin, Ph. Pettit (eds.), Contemporary Political Philosophy: an anthology (Oxford, Malden (Mass.), Blackwell, 1998)

18. K. Dzhouitt, New World Disorder: The Leninist Extinctio (University of California Press, Berkeley, 1992)

19. K. Ohmae, The End of the Nation State (The Free Press, New York, 1996)

20. G.H. von Wright, Associations 1, 4 (1997)

21. F. Fukuyama. Nashe Postchelovecheskoe budushchee [Our Posthuman Future], (Moscow, 2004)

22. I.L. Chestnov, Dialogic Methodology of Legal Science, in Metodologicheskie problemy sovremennoy yuridicheskoy nauki [Methodological Problems of Modern Legal Science] (Rusayns Publ., Moscow, 2015)

23. Transformatsiya pravovoy realnosti $v$ tsifrovuyu epokhu [Transformation of Legal Reality in the Digital Epoch], in D.A. Pashentsev (ed.), Collection of scientific proceedings] (Infra-M Publ., Moscow, 2019) 